\title{
Factors of fertility ageing rate
}

\author{
Nelly S. Smulyanskaya ${ }^{1}$ \\ 1 Lomonosov Moscow State University, Moscow, 119991, Russia
}

Received 16 October 2019 • Accepted 18 February 2020 • Published 31 March 2020

Citation: Smulyanskaya NS (2020) Factors of fertility ageing rate. Population and Economics 4(1): 60-74. https:// doi.org/10.3897/popecon.4.e53039

\begin{abstract}
The current demographic model of most developed countries is characterized by ageing and declining fertility. Despite the fact that this topic has been studied quite thoroughly, the question remains: what national indicators does the rate of ageing fertility depend on in different groups of countries? An analysis of some developed countries between 1990 and 2017 enables concluding that the dynamics of intensity of the first births over the age of 35 in the group of developed countries is negatively influenced by the dynamics of employment and the share of services in GDP, while the maternal age at first birth in the group of former socialist countries depends on the dynamics of the education indicator.
\end{abstract}

\section{Keywords}

fertility ageing, birth factors, birth models, second demographic transition

JEL codes: J10, J13

\section{Introduction}

Late and low fertility has been one of the characteristics of the demographic model in developed countries over the past few decades. In the more developed countries, this process began in the 1970s. The process found a theoretical justification in D. van de Kaa and R. Lesthaeghe's theory of the second demographic transition. The main reason for this situation is the change in sociocultural norms in a society in which the individual with his or her personal needs and desires has come to the fore. In macroeconomic terms, the second demographic transition has been accompanied by an increase in the share of employed women (Mosakova 2012) and, as a consequence, growth of the economy as a whole. At the same time, the decrease in the number of young people (which in future will become the main labour force) within a generation leads to a sharp increase in the pension burden on the working-age population. Germany and France were the first countries to experience the 
effects of low fertility and to come to the conclusion that there was a need for government intervention in this issue. In the former socialist countries, this process has been considerably delayed. In the former republics of the USSR and the former socialist countries an active fertility ageing process began only in the 1990s after the collapse of the socialist political system. The socialist regime was characterized by a traditional demographic model (early motherhood, a high total fertility rate (TFR) for first births, low proportion of births out of wedlock etc.) (Frejka and Sardon 2006).

After major changes in demographic behaviour patterns in the most developed countries, demographic science has multiplied theories explaining the causes of fertility decline and postponement of childbirth. According to some theories, the main factor in fertility decline is partners' self-esteem of their financial well-being and higher parents' demands for the upbringing of their children (Becker 1987; Darsky 1979; Easterlin 1969; Schultz 1994). Other theories explain the current demographic situation by the change in socio-emotional need of a family for children (Antonov and Medkov 1996; Borisov 1976). Gender equality theories (McDonald 2000; Kalabikhina 2009) state a relationship between the number of children in the family and the distribution of social and domestic responsibilities among partners.

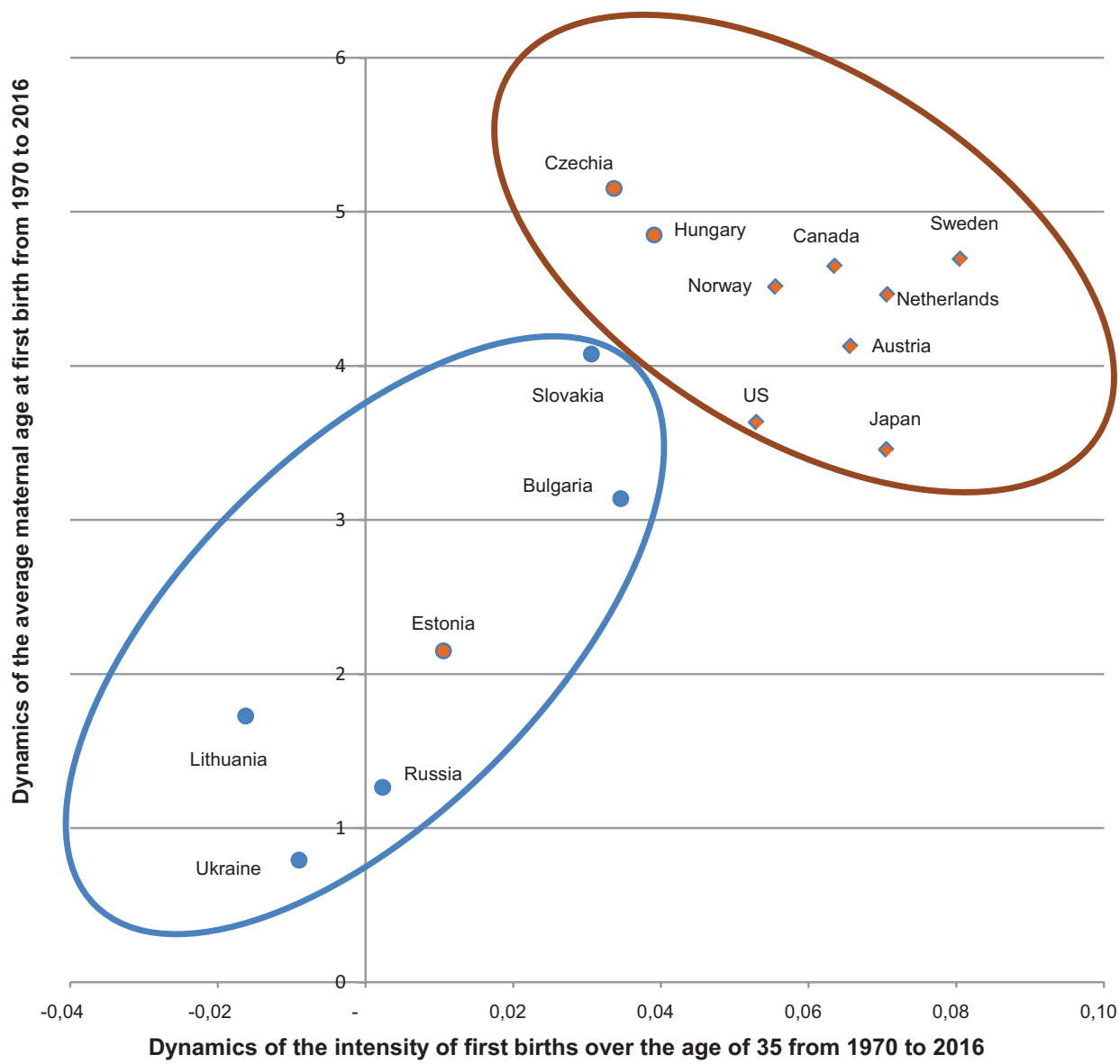

Figure 1. The dynamics of the fertility ageing indicators over 40 years (1970-2010). Source: Human Fertility Database, Rosstat, author's calculations 
All of the above-mentioned papers study fertility indicators and/or their dynamics, not the rate of change. There are very few works on the study of the determinants of fertility ageing rate among older women in Russian demographic science.

The process of increasing fertility in older ages should be separated from the process of delayed childbearing. These two processes can go in parallel and have a similar result, but different causes and possible development options. In this study the process of increasing fertility is measured by the share of first births over the age of 35 and the postponement of childbearing is measured by the woman's mean age at first birth (MAB1).

Figure 1 shows the changes in the intensity of first births over the age of 35 (the $x$-axis) and the mean age at first birth (the y-axis). The change in life expectancy (LE) in the country during the period under study is marked in color. Blue indicates that the LE has increased by less than 5.5 years, red - by over 5.5 years. The shape of the marker reflects the dynamics of the share of women with higher education. Countries in which the share of women with higher education increased by less than 20 percentage points are shaped as circles and countries where the increase was more than 20 percentage points are shaped as rhombi.

As shown in Figure 1, all the countries under review can be divided into two broad groups: the first include the most developed countries, which have undergone significant changes in fertility patterns (the increase in the mean maternal age at birth and the growth of the share of first births over the age of 35) and LE over the past 40 years, and the second include former socialist countries where changes were less intense.

If we draw a trend line within each group, we see that for the second group of countries the increase in the mean maternal age and the share of first births over the age of 35 occurred in parallel, while in the more developed countries the increase in the share of first births over the age of 35 occurred with no further growth of the mean maternal age. It is clear that, under current conditions, for these countries, the mean maternal age of 28 is a certain limit (for psychological, physiological or other reasons) after which women are no longer inclined to postpone the childbearing despite all modern socio-economic challenges. Obviously, there is also a growth limit of the first-birth rates among women over the age of 35 . But so far, even in countries with the latest birth rate, the proportion of late first births does not exceed $13-15 \%$ (of the total number of first-borns), although it continues to rise.

In the countries under review, the cumulative first-birth rates (CBR1) over the age of 35 rose by 2-5 times in most countries between 1990 and 2014. Record growth was observed only in the Czech Republic, where the indicator grew by 8 times. The Czech phenomenon is associated with the "quick start" and a faster second demographic transition. At the same time, as noted above, in the former socialist countries up to 1998 there was some
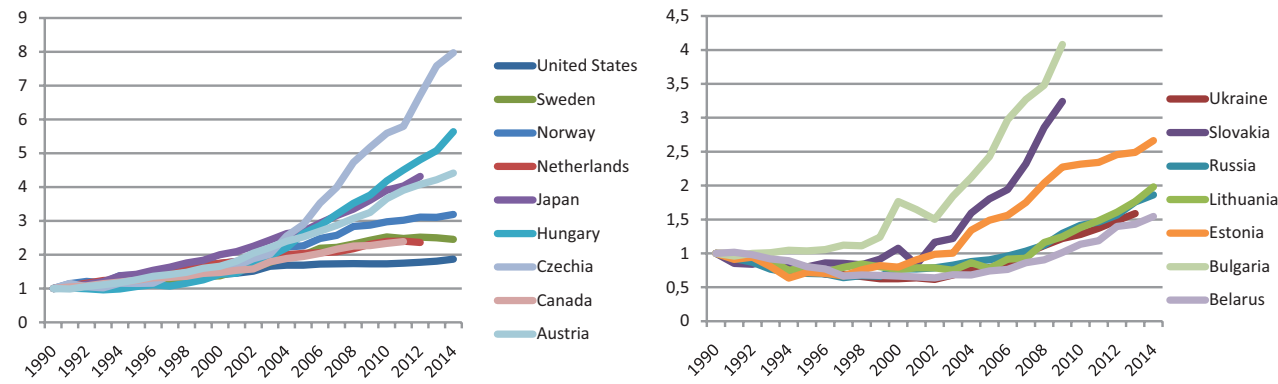

Figure 2. The dynamics of the share of first births in the TFR for women over 35 years of age compared to 1990. Source: Human Fertility Database, Rosstat, author's calculations. 
"rejuvenation" of fertility associated with the social and economic crisis after the collapse of the USSR.

Figure 2 shows that the countries of the second group (former socialist bloc) have experienced a temporary decline in the first-birth rates between 1998 and 2004 compared to the same indicator for 1990.

The mean age at first birth increased in all the countries under review, and the growth varied from $5 \%$ over 24 years for the most developed countries in which the ageing process had begun long ago (Japan, Sweden and the Netherlands), up to 25\% in the Czech Republic.
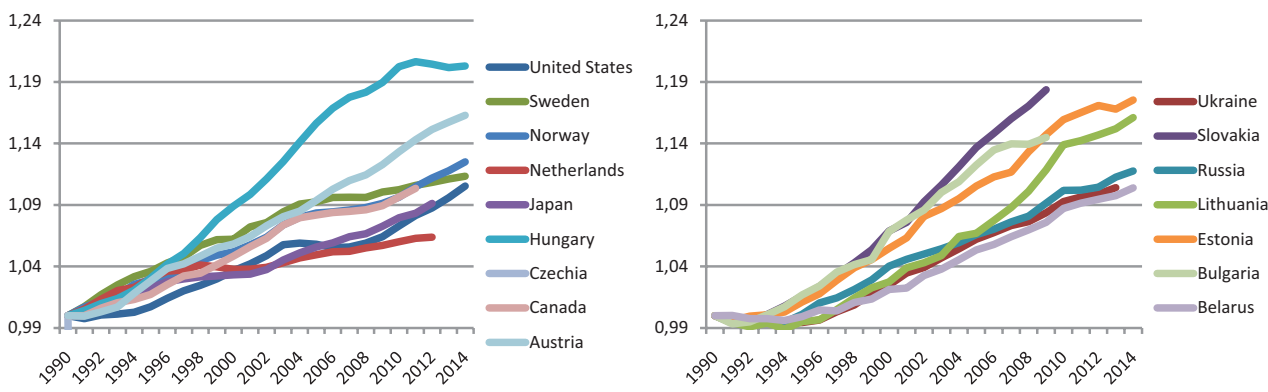

Figure 3. Dynamics of the mean maternal age at first birth compared to 1990. Source: Human Fertility Database, Rosstat, author's calculations.

Figure 3 shows the dynamics of the mean maternal age at first birth compared to 1990. The graphs show that in the second group of countries, the indicator hardly grew until 1995, however after that it grew almost more intensively than in the countries of the first group.

The analysis indicates that both the postponement of childbearing and the increase in fertility in older ages occur at different rates in different developed countries. This raises the question: the dynamics of which country's characteristics affects fertility ageing rate, i.e. the dynamics of the analyzed demographic indicators?

In several studies analyzing the relationship between macroeconomic indicators and fertility, we can identify some interrelationships between demographic indicators and country's parameters. However, the impact of GDP on fertility is quite controversial. Thus, some authors consider the decline in fertility as a result of economic crisis, which can be compensated later by a shift in the birth calendar (Neels 2010; Kohler et al. 2002; Mills and Blossfeld 2005). The opposite view (Billingsley 2010; Butz and Ward 1979) is that, during a period of economic recovery, the alternative cost of childbearing increases and this affects fertility decline, i.e. fertility is countercyclical to the economy.

The analysis of employment and fertility in developed countries revealed a change in the interdependence from negative to positive (; Pampel 2001). Although, for instance, according to Mishra et al. (2010), cause-effect is inverse, and the increase in the TFR leads to a decline in women's employment.

The relationship between demographic processes and education is studied from several perspectives of mutual influence. Thus, in several works the relationship between late motherhood and the age of graduation has been proven (Black et al. 2008; Monstad et al. 2008; Silles 2011). Some works are aimed at identifying the degree of influence of the education factor on delayed family formation (Neels 2010; Neels and De Wachter 2010). The research results have shown that this effect is quite significant. 
The mentioned papers show the influence of socio-economic factors on demographic indicators. This study attempts to identify the extent of the impact of changes in national socio-economic characteristics on changes in the indicators of fertility ageing.

\section{Hypotheses}

When making hypotheses, attention should be paid to the fact that for the indicator of the intensity of births after the age of 35, they may vary depending on the order of a birth of a child. It should be noted that further analysis was done only for the first birth indicator for the sake of "cleanliness" in relationship identification.

Hypotheses concerning the dependence of the dynamics of the analyzed variables and the dynamics of the indicators of fertility ageing are presented in Table 1.

Table 1. Hypotheses regarding the dynamics of analyzed variables.

\begin{tabular}{|c|c|c|}
\hline Variable & $\begin{array}{c}\text { Impact on the share of births } \\
\text { over the age of } 35\end{array}$ & $\begin{array}{c}\text { Effect on the maternal age } \\
\text { at first birth }\end{array}$ \\
\hline GDP & $\begin{array}{l}\text { The influence is twofold: first births at } \\
\text { this age can be the result of a country's } \\
\text { economic development, higher-or- } \\
\text { der births correlate with poverty and } \\
\text { lower quality of human capital in the } \\
\text { society. }\end{array}$ & $\begin{array}{l}\text { The effect is positive. Later motherhood } \\
\text { is usually the result of economic devel- } \\
\text { opment in the country and the financial } \\
\text { sustainability of the household. }\end{array}$ \\
\hline Employment & $\begin{array}{l}\text { Greater employment reduces the free } \\
\text { time that a woman would alternatively } \\
\text { spend on the birth and upbringing of } \\
\text { children. The impact is negative. }\end{array}$ & $\begin{array}{l}\text { The effect is positive. Entry into the la- } \\
\text { bour market shifts the life cycle of the } \\
\text { woman, including childbearing. }\end{array}$ \\
\hline Infant mortality & $\begin{array}{l}\text { The more children die, the greater is the } \\
\text { need for additional births. The effect is } \\
\text { positive. }\end{array}$ & $\begin{array}{l}\text { The more children die, the sooner it is } \\
\text { necessary to begin a maternal life. The } \\
\text { impact is negative. }\end{array}$ \\
\hline Education & $\begin{array}{l}\text { The influence is twofold: first births } \\
\text { at this age can be the result of higher } \\
\text { education, then the impact is pos- } \\
\text { itive, higher order births correlate } \\
\text { with poverty and lower levels of ed- } \\
\text { ucation. }\end{array}$ & $\begin{array}{l}\text { Higher levels of education lead to a de- } \\
\text { layed family life. If time spent on start- } \\
\text { ing a career is added to the time spent } \\
\text { on education, the effect will increase. } \\
\text { The effect is positive. }\end{array}$ \\
\hline $\mathrm{LE}$ & $\begin{array}{l}\text { If we consider LE as an indicator of the } \\
\text { quality of life, the impact is positive } \\
\text { (higher levels of reproductive health } \\
\text { and greater economic opportunities for } \\
\text { the birth and upbringing). }\end{array}$ & $\begin{array}{l}\text { The effect is positive. The increase in LE } \\
\text { leads to a longer planning horizon and } \\
\text { the possibility of later childbearing. }\end{array}$ \\
\hline $\begin{array}{l}\text { Share of the ser- } \\
\text { vices sector }\end{array}$ & $\begin{array}{l}\text { The impact is positive - the greater } \\
\text { is the labour market for women, the } \\
\text { greater is the likelihood of childbearing } \\
\text { after some time of labour activity. }\end{array}$ & $\begin{array}{l}\text { The impact is positive - the greater } \\
\text { is the labour market for women, the } \\
\text { greater is the likelihood of childbearing } \\
\text { after some time of labour activity. }\end{array}$ \\
\hline
\end{tabular}




\section{Methodology}

In this study, a regression analysis of the dependence (least-squares method) was carried out. The dependent variable are the changes in the TFR indicators for the first births of women over the age of 35 per year (model 1) and the mean maternal age at first birth (model 2). The dependent variable was taken with a one-year time lag that is required for the childbearing. The data source is the HFD database. Countries for which birth order data are available are selected from the database.

Independent variables are the changes over the year of the following country's characteristics:

- GDP per capita (current prices, USD);

- employment of women;

- infant mortality;

- enrollment in higher education;

- LE;

- the share of services in GDP.

The data source is the World Bank database.

Analyzed period is 1990-2014 (there are data gaps on a longer period for most countries). For preliminary analysis of results and identification of the problem of multicollinearity a correlation matrix for indicators of both groups of countries has been constructed (Tables 2,3 ).

Table 2. Correlation matrix between indicators for the first group of countries.

\begin{tabular}{|c|c|c|c|c|c|c|c|c|}
\hline CBR1 35+ & MAB1 & GDP & Work & Education & LE & Services & $\begin{array}{c}\text { Infant } \\
\text { mortality }\end{array}$ & \\
\hline \multirow[t]{8}{*}{1} & 0.00 & 0.14 & 0.28 & 0.13 & -0.11 & -0.17 & -0.15 & CBR1 35+ \\
\hline & 1 & -0.15 & -0.28 & 0.22 & 0.00 & 0.08 & -0.07 & MAB1 \\
\hline & & 1 & 0.40 & 0.27 & -0.05 & -0.20 & 0.03 & GDP \\
\hline & & & 1 & 0.05 & -0.18 & -0.07 & 0.11 & Work \\
\hline & & & & 1 & -0.03 & 0.00 & -0.15 & Education \\
\hline & & & & & 1 & -0.13 & -0.02 & $\mathrm{LE}$ \\
\hline & & & & & & 1 & 0.01 & Services \\
\hline & & & & & & & 1 & Infant mortality \\
\hline
\end{tabular}

Source: Human Fertility Database, World Development Indicators Database, author's calculations.

Table 3. Correlation matrix between indicators for the second group of countries.

\begin{tabular}{lllllllll}
\hline CBR1 35+ & MAB1 & GDP & Work & Education & LE & Services & $\begin{array}{c}\text { Infant } \\
\text { mortality }\end{array}$ \\
\hline 1 & & & & & & & & \\
& 1 & -0.36 & 0.29 & -0.10 & -0.05 & -0.32 & -0.20 & CBR1 35+ \\
& & 1 & 0.30 & 0.11 & -0.13 & -0.34 & -0.32 & GDP \\
& & & 1 & -0.02 & -0.04 & -0.11 & -0.16 & Work \\
& & & 1 & -0.25 & 0.23 & 0.10 & Education \\
& & & & 1 & 0.09 & -0.24 & LE \\
& & & & & 1 & 0.18 & Services \\
& & & & & & & 1 & Infant mortality \\
\hline
\end{tabular}

Source: Human Fertility Database, World Development Indicators database, author's calculations. 
According to results presented in the correlation matrix, there are no significant relationships between the variables at all. On the one hand, this reduces the risk of multicollinearity. On the other hand, low correlation indicates a high risk of lacking significant links between the dynamics of the analyzed indicators.

Models were separately built for the former socialist countries (Ukraine, Russia, Lithuania, Hungary, Czech Republic, Bulgaria, Belarus and Slovakia) and for the rest of the capitalist countries. An attempt was also made to build a common model with a dummy variable for the socialist group of countries. In such a model, the dummy variable was insignificant.

\section{Results}

Based on the results of econometric modelling the conclusions presented in Table 4 and Table 5 are obtained. All characteristics of the obtained models are presented in the Appendix.

The results show that the dynamics of childbearing intensity over the age of 35 in the former socialist countries are not affected by any factor under review. In the group of developed countries, the negative impact of employment and the share of services in GDP (as sectors with a high share of female labour) are significant. The alleged explanation is that young women are willing to give birth sooner (the birth of the first child after the age of 35 is gradually becoming the norm in these countries rather than an exception) in the absence (or a significant reduction) of the alternative of work.

For all countries, the constant and the dynamics of infant mortality are significant, which is contrary to the hypothesis. The inability to explain this dependence calls the robustness of the model into question.

Table 4. Dependent variable - dynamics of the birth rate of the first child for women over 35 years old.

\begin{tabular}{|c|c|c|c|c|c|c|c|c|}
\hline Country & const & GDP & Employment & Education & $\begin{array}{c}\text { Infant } \\
\text { mortality }\end{array}$ & LE & $\begin{array}{l}\text { Share of } \\
\text { services }\end{array}$ & $\mathbf{R}^{2}$ \\
\hline $\begin{array}{l}\text { Former socialist } \\
\text { countries }\end{array}$ & & & & & & & & 0.2 \\
\hline $\begin{array}{l}\text { Developed capi- } \\
\text { talist countries }\end{array}$ & & & - & & & & - & 0.0 \\
\hline All countries & + & & & & + & & & 0.1 \\
\hline
\end{tabular}

Source: Author's calculations.

Table 5. Dependent variable - the change in average maternal age at first birth.

\begin{tabular}{|c|c|c|c|c|c|c|c|c|}
\hline Country & const & GDP & Employment & Education & $\begin{array}{c}\text { Infant } \\
\text { mortality }\end{array}$ & LE & $\begin{array}{l}\text { Share of } \\
\text { services }\end{array}$ & $\mathbf{R}^{2}$ \\
\hline $\begin{array}{l}\text { Former socialist } \\
\text { countries }\end{array}$ & & & & + & & & & 0.1 \\
\hline $\begin{array}{l}\text { Developed capi- } \\
\text { talist countries }\end{array}$ & & & & & & & & 0.0 \\
\hline All countries & & & & & & & & 0.0 \\
\hline
\end{tabular}

Source: Author's calculations. 
Unfortunately, low $\mathrm{R}^{2}$ indicates that a large share of changes in the intensity of births after 35 years is not attributable to the factors considered.

The analysis shows that the change in the birth calendar in the former socialist countries depends on education and this corresponds with the hypothesis. Other variables are insignificant.

Unfortunately, models with average maternal age at first birth as the dependent variable also have a very low $\mathrm{R}^{2}$.

\section{Conclusion}

It can be concluded that country's characteristics do not explain a large share of changes in demographic indicators. This may suggest that the postponement of childbirth is rather inertial, and the process that started at some point (women's active participation in the labour market, their high level of education and the growth of its duration) has almost no reverse movement regardless of socio-economic fluctuations in the country. The average age of childbearing in the former socialist countries confirms this statement. The dynamics of fertility ageing indicators may depend both on the accumulated effect of several previous years and on the situation in which the country was at the beginning of the study ("quick start" etc.).

The dynamics of childbirth intensity in the group of developed capitalist countries is negatively influenced by the dynamics of employment and the share of services in GDP. And the dynamics of the maternal age at first birth in the group of former socialist countries depends on the dynamics of the education indicator.

As a result, it can be concluded that the change in the average maternal age at first birth is also more "sensitive" to the change in the share of women with higher education in the former socialist countries, and to change in labour market participation in developed capitalist countries. However, the models obtained explain only a small proportion of the changes in the analyzed demographic indicators. A possibly important factor influencing the dynamics of demographic indicators, but not included in the model, may be the stability of social traditions and stereotypes in the country, but this indicator is quantitatively immeasurable.

\section{Reference list}

Antonov AI, Medkov VM (1996) Sociology of the family. Moscow University Publishing House and the Publishing House of the International University of Business and Management ("Karich Brothers"), Moscow, 304 pp. (in Russian)

Becker G (1987) Economic Analysis and Human Behavior. In: Green L, Kagel J (Eds.) Advances in Behavioral Sciences. Norwood (N.J.): Ablex Publ. Corp., 3-17.

Billingsley S (2010) The post-communist fertility puzzle. Population Research and Policy Review 29 (2): 193-231. https://link.springer.com/article/10.1007/s11113-009-9136-7 [Accessed on 04.04.2020]

Black SE, Devereux PJ, Salvanes KG (2008) Staying in the classroom and out of the maternity ward? The effect of compulsory schooling laws on teenage births. Economic Journal 118 (530): 10251054. https://doi.org/10.1111/j.1468-0297.2008.02159.x

Blossfeld H-P, Klijzing E, Mills M, Kurz K (2005) Globalisation, uncertainty, and youth in society, Routledge, London.

Borisov VA (1976) Birth prospects. Statistics, Moscow, 248 pp. http://www.demoscope.ru/weekly/ knigi/borisov/borisov.pdf [Accessed on 04.04.2020] (in Russian) 
Butz WP, Ward MP (1979) The emergence of countercyclical U.S. fertility. The American Economic Review 69 (3): 318-328. https://www.jstor.org/stable/1807367 [Accessed on 04.04.2020]

Darsky LB (1979) Fertility and the reproductive function of the family. In: Volkov AG (Ed) Demographic development of the family. Statistics, Moscow, 85-123 (in Russian)

Easterlin RA (1969) Towards a socioeconomic theory of fertility: A survey of recent research on economic factors in American fertility. In: Behrman SJ, Corsa JL, Freedman R (Eds.) Fertility and family planning: A world view. Ann Arbor, University of Michigan Press, 127-156.

Frejka T, Sardon J-P (2006) First Birth Trends in Developed Countries: Persisting Parenthood Postponement. Demographic Research 15: 147-180. www.jstor.org/stable/26347910 [Accessed on 04.04.2020]

Kalabikhina IE (2009) The Gender Factor in the Economic Development of Russia. Max PRSS, Moscow, 238 pp. https://elibrary.ru/item.asp?id=19906527 [Accessed on 04.04.2020] (in Russian)

Kohler H-P, Billari FC, Ortega JA (2002) The emergence of lowest-low fertility in Europe duringthe 1990s. Population and Development Review 28 (4): 641-681. https://doi.org/10.1111/j.17284457.2002.00641.x [Accessed on 07.04.2020]

McDonald P (2000) Gender equity in theories of fertility transition. Population and Development Review 26 (3): 427-439. https://doi.org/10.1111/j.1728-4457.2000.00427.x

Mills M, Blossfeld, H-P (2005) Globalization, uncertainty and the early life course: A theoretical framework. In: Blossfeld H-P, Klijzing E, Mills M, Kurz K (Eds.) Globalization, uncertainty and youth in society. Routledge, London, 1-24.

Mishra V, Nielsen I, Smyth R (2010) On the relationship between female labour force participation and fertility in G7 countries: Evidence from panel cointegration and Granger causality. Empirical Economics 38: 361-372. https://doi.org/10.1007/s00181-009-0270-1

Monstad K., Propper C, Salvanes KG (2008) Education and fertility: evidence from a natural experiment. Scandinavian Journal of Economics 110 (4): 827-852. https://doi.org/10.1111/j.14679442.2008.00563.x

Mosakova EA (2012) Dynamics of fertility and employment of women in modern developed countries. Voronezh State University Bulletin. Series: Economics and Management [Vestnik Voronezhskogo gosudarstvennogo universiteta. Seriya: ehkonomika i upravlenie] (2): 36-44. https://elibrary. $\mathrm{ru} / \mathrm{item} . \mathrm{asp}$ ?id=18261995 [Accessed on 04.04.2020] (in Russian)

Neels K (2010) Temporal variation in unemployment rates and their association with tempo and quantum of fertility: Some evidence for Belgium, France and the Netherlands. https://pdfs.semanticscholar.org/4721/4d9ef9e0fb127e5aled1ccd41e5a8318b86c.pdf [Accessed on 04.04.2020]

Neels K, De Wachter D (2010) Postponement and recuperation of Belgian fertility: How are they related to rising female educational attainment? Vienna Yearbook of Population Research 8: 77-106. https://www.jstor.org/stable/23025511 [Accessed on 04.04.2020]

Pampel FC (2001) The institutional context of population change. University of Chicago Press. https:// www.degruyter.com/view/title/560312 [Accessed on 04.04.2020]

Schultz T (1994) Fertility and Economic Values. Part I: The Value of Children. In: Schultz T (Ed) Economics of the Family. University of Chicago Press, Chicago, 3-14.

Silles MA (2011) The effect of schooling on teenage childbearing: evidence using changes in compulsory education laws. Journal of Population Economics 24: 761-777. https://oi.org/10.1007/ s00148-010-0334-8

\section{Author details:}

- Nelly Stanislavovna Smulyanskaya, Ph.D., Lomonosov Moscow State University. E-mail: nsmulya@mail.ru 


\section{Appendix}

Model 1. All observations, dependent variable - delta of TFR for first births of women over the age of 35 .

Model's report

\begin{tabular}{ccccc}
\hline Model & $\mathbf{R}$ & $\mathbf{R}^{2}$ & Adjusted $\mathbf{R}^{2}$ & $\begin{array}{c}\text { Standard error } \\
\text { of estimate }\end{array}$ \\
\hline 1 & $.374^{\mathrm{a}}$ & .140 & .112 & .07757 \\
\hline
\end{tabular}

Predictors: (constant), countype, labour, services, educ, LAB, GDP, mortality

\section{ANOVA ${ }^{a}$}

\begin{tabular}{lccccc}
\hline Model & $\begin{array}{c}\text { Sum } \\
\text { of squares }\end{array}$ & df & $\begin{array}{c}\text { Mean } \\
\text { square }\end{array}$ & F & Sig. \\
\hline 1 Regression & .215 & 7 & .031 & 5.098 & $.000^{\mathrm{b}}$ \\
Residual & 1.324 & 220 & .006 & & \\
Total & 1.538 & 227 & & & \\
\hline
\end{tabular}

Dependent variable: TFR

Predictors: (constant), countype, labour, services, educ, LAB, GDP, mortality

\section{Coefficients $^{a}$}

\begin{tabular}{lccccc}
\hline \multirow{1}{*}{ Model } & \multicolumn{2}{c}{$\begin{array}{c}\text { Unstandardized } \\
\text { coefficients }\end{array}$} & $\begin{array}{c}\text { Standardized } \\
\text { coefficients }\end{array}$ & T & Sig. \\
\cline { 2 - 4 } & B & Std. error & Beta & & \\
\hline 1constant & .002 & .017 & & .108 & .914 \\
GDP & .329 & .168 & .224 & 1.956 & .052 \\
Labour & .290 & .282 & .083 & 1.029 & .305 \\
Educ & .078 & .094 & .068 & .831 & .407 \\
LAB & -.816 & 1.491 & -.098 & -.547 & .585 \\
Services & -.263 & .166 & -.113 & -1.599 & .113 \\
Mortality & .007 & .044 & .034 & .159 & .874 \\
Countype & .039 & .013 & .223 & 3.014 & .003 \\
\hline
\end{tabular}

Dependent variable: TFR 
Model 2. All observations, dependent variable - delta of average maternal age at first birth.

Model's report

\begin{tabular}{ccccc}
\hline Model & $\mathbf{R}$ & $\mathbf{R}^{2}$ & Adjusted $^{2}$ & $\begin{array}{c}\text { Standard error } \\
\text { of estimate }\end{array}$ \\
\hline 1 & $.148^{\mathrm{a}}$ & .002 & -.009 & .01424 \\
\hline
\end{tabular}

Predictors: (constant), countype, labour, services, educ, LAB, GDP, mortality

ANOVA $^{a}$

\begin{tabular}{lccccc}
\hline Model & $\begin{array}{c}\text { Sum of } \\
\text { squares }\end{array}$ & df & Mean square & F & Sig. \\
\hline 1 Regression & .001 & 7 & .000 & .708 & $.666^{\mathrm{b}}$ \\
Residual & .045 & 220 & .000 & & \\
Total & .046 & 227 & & & \\
\hline
\end{tabular}

Dependent variable: $\mathrm{MAB}$

Predictors: (constant), countype, labour, services, educ, LAB, GDP, mortality

\section{Coefficients $^{a}$}

\begin{tabular}{lccccc}
\hline \multicolumn{1}{c}{ Model } & \multicolumn{2}{c}{$\begin{array}{c}\text { Unstandardized coeffi- } \\
\text { cients }\end{array}$} & $\begin{array}{c}\text { Standardized } \\
\text { coefficients }\end{array}$ & T & Sig. \\
\cline { 2 - 5 } & B & Std. error & Beta & & \\
\hline 1constant & .001 & .003 & & .324 & .746 \\
GDP & -.008 & .031 & -.031 & -.255 & .799 \\
Labour & -.027 & .052 & -.044 & -.516 & .606 \\
Educ & .023 & .017 & .115 & 1.326 & .186 \\
LAB & -.192 & .274 & -.135 & -.702 & .484 \\
Services & .006 & .030 & .015 & .192 & .848 \\
Mortality & -0.002 & .008 & -.065 & -.289 & .773 \\
Countype & .003 & .002 & .095 & 1.202 & .231 \\
\hline
\end{tabular}

Dependent variable: $\mathrm{MAB}$ 
Model 3. Countries of the first group, dependent variable - delta of average maternal age at first birth.

Model's report

\begin{tabular}{ccccc}
\hline Model & $\mathbf{R}$ & $\mathbf{R}^{2}$ & Adjusted $\mathbf{R}^{2}$ & $\begin{array}{c}\text { Standard error } \\
\text { of estimate }\end{array}$ \\
\hline 1 & $.155^{\mathrm{a}}$ & .024 & -.016 & .01725 \\
\hline
\end{tabular}

Predictors: (constant), labour, services, educ, LAB, GDP, mortality

ANOVA $^{a}$

\begin{tabular}{lccccc}
\hline \multicolumn{1}{c}{ Model } & Sum of squares & df & Mean square & F & Sig. \\
\hline 1 Regression & .001 & 6 & .000 & .592 & $.737^{\mathrm{b}}$ \\
Residual & .043 & 145 & .000 & & \\
Total & .044 & 151 & & & \\
\hline
\end{tabular}

Dependent variable: $\mathrm{MAB}$

Predictors: (constant), labour, services, educ, LAB, GDP, mortality

\section{Coefficients $^{a}$}

\begin{tabular}{lccccc}
\hline \multirow{1}{*}{ Model } & \multicolumn{2}{c}{$\begin{array}{c}\text { Unstandardized } \\
\text { coefficients }\end{array}$} & $\begin{array}{c}\text { Standardized } \\
\text { coefficients }\end{array}$ & T & Sig. \\
\cline { 2 - 4 } & $\mathbf{B}$ & Std. error & Beta & & \\
\hline 1constant & .003 & .002 & & 1.708 & .090 \\
GDP & .031 & .070 & .099 & .446 & .656 \\
Labour & -.052 & .093 & -.071 & -.565 & .573 \\
Educ & .031 & .026 & .143 & 1.217 & .226 \\
LAB & -.465 & .507 & -.318 & -.917 & .360 \\
Services & .025 & .071 & .035 & .347 & .729 \\
Mortality & -0.004 & .014 & -.120 & -.291 & .771 \\
\hline
\end{tabular}

Dependent variable: $\mathrm{MAB}$ 
Model 4. Countries of the first group, dependent variable - delta of TFR for first births of women over the age of 35 .

Model's report

\begin{tabular}{ccccc}
\hline Model & $\mathbf{R}$ & $\mathbf{R}^{2}$ & Adjusted $\mathbf{R}^{2}$ & $\begin{array}{c}\text { Standard error } \\
\text { of estimate }\end{array}$ \\
\hline 1 & $.213^{\mathrm{a}}$ & .045 & .006 & .08227 \\
\hline
\end{tabular}

Predictors: (constant), labour, services, educ, LAB, GDP, mortality

ANOVA $^{a}$

\begin{tabular}{lccccc}
\hline \multicolumn{1}{c}{ Model } & Sum of squares & Df & Mean square & F & Sig. \\
\hline 1 Regression & .047 & 6 & .008 & 1.148 & $.338^{\mathrm{b}}$ \\
Residual & .981 & 145 & .007 & & \\
Total & 1.028 & 151 & & & \\
\hline
\end{tabular}

Dependent variable: TFR

Predictors: (constant), labour, services, educ, LAB, GDP, mortality

\section{Coefficients $^{a}$}

\begin{tabular}{lccccc}
\hline \multirow{1}{*}{ Model } & \multicolumn{2}{c}{$\begin{array}{c}\text { Unstandardized } \\
\text { coefficients }\end{array}$} & $\begin{array}{c}\text { Standardized } \\
\text { coefficients }\end{array}$ & T & Sig. \\
\cline { 2 - 4 } & $\mathbf{B}$ & Std. error & Beta & & \\
\hline lconstant & .039 & .010 & & 4.094 & .000 \\
GDP & .328 & .336 & .213 & .975 & .331 \\
Labour & -.023 & .443 & .007 & -.053 & .958 \\
Educ & .174 & .122 & .166 & 1.425 & .156 \\
LAB & -2.033 & 2.418 & -.288 & -.841 & .402 \\
Services & -.054 & .340 & -.016 & -.158 & .875 \\
Mortality & -.016 & .068 & -.093 & -.229 & .819 \\
\hline
\end{tabular}

Dependent variable: TFR 
Model 5. Countries of the second group, dependent variable - delta of TFR for first births of women over the age of 35 .

Model's report

\begin{tabular}{ccccc}
\hline Model & $\mathbf{R}$ & $\mathbf{R}^{2}$ & Adjusted $\mathbf{R}^{2}$ & $\begin{array}{c}\text { Standard error } \\
\text { of estimate }\end{array}$ \\
\hline 1 & $.466^{\mathrm{a}}$ & .217 & .149 & .06730 \\
\hline
\end{tabular}

Predictors: (constant), labour, services, educ, LAB, GDP, mortality

ANOVA $^{a}$

\begin{tabular}{lccccc}
\hline \multicolumn{1}{r}{ Model } & Sum of squares & Df & Mean square & F & Sig. \\
\hline 1 Regression & .087 & 6 & .014 & 3.188 & $.008^{\text {b }}$ \\
Residual & .312 & 69 & .005 & & \\
Total & .399 & 75 & & & \\
\hline
\end{tabular}

Dependent variable: TFR

Predictors: (constant), labour, services, educ, LAB, GDP, mortality

\section{Coefficients $^{a}$}

\begin{tabular}{lccccc}
\hline \multirow{2}{*}{ Model } & \multicolumn{2}{c}{ Unstandardized coefficients } & $\begin{array}{c}\text { Standardized } \\
\text { coefficients }\end{array}$ & T & Sig. \\
\cline { 2 - 4 } & $\mathbf{B}$ & Std. error & Beta & & \\
\hline lconstant & .080 & .017 & & 4.681 & .000 \\
GDP & .310 & .178 & .221 & 1.740 & .086 \\
Labour & .557 & .355 & .187 & 1.661 & .101 \\
Educ & -.107 & .153 & -.081 & -.696 & .489 \\
LAB & -.477 & 1.804 & -.031 & -.264 & .792 \\
Services & -.278 & .175 & -.191 & -1.589 & .117 \\
Mortality & -.123 & .226 & -.064 & -.542 & .590
\end{tabular}

Dependent variable: TFR 
Model 6. Countries of the second group, dependent variable - delta of average maternal age at first birth.

Model's report

\begin{tabular}{ccccc}
\hline Model & $\mathbf{R}$ & $\mathbf{R}^{2}$ & Adjusted $\mathbf{R}^{2}$ & $\begin{array}{c}\text { Standard error } \\
\text { of estimate }\end{array}$ \\
\hline 1 & $.333^{\mathrm{a}}$ & .111 & .034 & .00376 \\
\hline
\end{tabular}

Predictors: (constant), labour, services, educ, LAB, GDP, mortality

ANOVA $^{a}$

\begin{tabular}{lccccc}
\hline \multicolumn{1}{c}{ Model } & Sum of squares & Df & Mean square & F & Sig. \\
\hline 1 Regression & .000 & 6 & .000 & 1.437 & $.213^{\mathrm{b}}$ \\
Residual & .001 & 69 & .000 & & \\
Total & .001 & 75 & & & \\
\hline
\end{tabular}

Dependent variable: MAB

Predictors: (constant), labour, services, educ, LAB, GDP, mortality

Coefficients $^{a}$

\begin{tabular}{lccccc}
\hline \multirow{2}{*}{ Model } & \multicolumn{2}{c}{ Unstandardized coefficients } & $\begin{array}{c}\text { Standardized } \\
\text { coefficients }\end{array}$ & T & Sig. \\
\cline { 2 - 4 } & \multicolumn{1}{c}{$\mathbf{B}$} & Std. error & Beta & & \\
\hline 1constant & .007 & .001 & & 7.792 & .000 \\
GDP & -.022 & .010 & .301 & -2.218 & .030 \\
Labour & -.016 & .019 & -.100 & -.832 & .408 \\
Educ & $-9.738 \mathrm{E}-7$ & .009 & .000 & .000 & 1.000 \\
LAB & -.094 & .101 & -.116 & -.932 & .355 \\
Services & .003 & .010 & .045 & .354 & .724 \\
Mortality & -.016 & .013 & -.156 & -1.234 & .221 \\
\hline
\end{tabular}

Dependent variable: $\mathrm{MAB}$ 